\title{
The Plague of Athens and the Cult of Asclepius: A Case Study of Collective Behavior and a Social Movement
}

\author{
Harry Perlstadt \\ Department of Sociology, Michigan State University, East Lansing, MI 48824, United States
}

Copyright $(2016$ by authors, all rights reserved. Authors agree that this article remains permanently open access under the terms of the Creative Commons Attribution License 4.0 International License

\begin{abstract}
During the Peloponnesian War between Athens and Sparta, several waves of a plague killed an estimated one-third of the civilian Athenian population and one-fourth of its army. Thucydides account of the plague (430-426 BCE) and the subsequent rise of the cult of Asclepius can be examined as perhaps the earliest case study of collective behavior and a social movement. In his account of the plague, Thucydides reveals a sociological imagination and concepts including anomie and escalating stages of collective behavior. Social movements often arise in times of sudden changes and social unrest, becoming a source of spiritual and political empowerment. The cult of Asclepius rose to prominence after the plague as a redemptive and reformative social movement. In the wake of the plague, the cult established new religious norms of healing and supported the growth of Hippocratic medicine throughout the ancient Mediterranean world.
\end{abstract}

Keywords Plague, Athens, Asclepius, Physicians, Collective Behavior, Social Movements

\section{Introduction}

The Athenian plague (430-426 BCE) can be examined as perhaps the earliest case study of what Miller [1] identifies as aspects and phases of collective behavior and reactions to an unusual event. Thucydides reported escalating stages of collective behavior: rumors, panic, general despair, not observing rituals and finally general lawlessness (anomia).

Following the plague and the peace of Nicias between Athens and Sparta in $421 \mathrm{BCE}$, the Athenians responded by rebuilding their city and their culture. The temple of Athena Nike (goddess of victory) on the Acropolis was completed in 420 BCE, Sophocles' tragedy Oedipus Rex was first produced at the Greater Dionysia in $425 \mathrm{BCE}$, and the cult of Asclepius arrived in Athens in 420 or 419 BCE. In his honor, Athens inaugurated a festival, providing prizes for the games, and built two major sanctuaries for healing and worship (Asclepieia), one on the south slope of the Acropolis and one in the port city of Piraeus. This marks the beginning of a new belief system that dealt with the failure to combat the plague.

Asclepius whose name means "to cut open," was cut from his dead mother's womb by his father Apollo. He was raised by the centaur Chiron who taught him the healing arts. His sons included Machaon and Podalirius, who served as surgeons and physicians during the Trojan War and among his daughters were Hygieia (health and sanitation) and Panacea (cure all). The cult of Asclepius was established towards end of the 6th century at Epidaurus, located in the Peloponnesus across the Saronic Gulf from Athens.

Over a short period of time Asclepius emergence from a local healing demigod to a Pan-Hellenic deity can be traced through coins minted in the last half of the fifth century BCE. He first appeared on coins minted in Larissa in Thessaly south of Mount Olympus between 450 and 400 BCE), Tricca in Thessaly, the home of his mother and sons between 400 and 344 BCE and Epidaurus between 400 and 350 BCE. He later appears on coins throughout the Greco-Roman world [2].

\section{Materials and Methods}

This is a case study and natural history of the societal response to the plague of Athens. It draws upon the primary observations and analysis of Thucydides account of the Peloponnesian war and Longrigg's "Epidemic, ideas and classical Athenian society" [3]. It utilizes the sociology of collective behavior and social movements as well as modern historical analyses of the plague of Athens and the cult of Asclepius. It then presents a set of historical stages in the development of a social movement that spread the teachings of Hippocrates across the Mediterranean world.

\section{Theoretical Perspectives}

Miller's [1] discussion of theories of collective behavior and social movements can shed light on the relationship between the plague of Athens and the rise of the cult of Asclepius. Thucydides mentioned atrocity rumors which 
attributed inhuman acts to an enemy, widespread anxiety and depression, hostile crowds, intense personal terror, mobilized evacuation and panicked fleeing to a safer location, overcrowding, acts of altruism in the face of disaster, and the strains on a society's culture, values and beliefs.

Collective behavior consists of actions not governed by everyday rules and expectations. While some theories focus on large crowds and riots [4-5], Smelser [6] presents a set of stages beginning with structural conduciveness and strain that spread generalized beliefs (rumors) that may generate panics, hostile outbursts and, in some cases, norm and value oriented movements. Under certain conditions institutional means are used to ameliorate the situation and modify social statuses, norms and values. Durkheim [7, p.248, $252-253,258]$ found that rapid and sudden changes in social, economic and personal relations can lead to normlessness and anomic suicide.

But anomie can also exist on a population level. Thucydides [8, §53]; [9, p.100-101] was the first to use the term anomia (óvouía), translated as lawlessness, in his description of the breakdown of moral and civil behaviors in Athens during the plague [10]. In the midst of the plague and after the second Peloponnesian invasion, [8,§59], [9, p.107] Pericles, the famous statesman and orator fell from favor and in a bizarre twist was deposed, tried, fined and reinstated as strategos (army leader). At one point facing a hostile and dejected crowd, he analyzed the situation, reinforced a normative structure, and raised morale:

"Happenings, which are sudden, unforeseen and contrary to all reasonable expectations, enslave the spirit. This has happened to you for various reasons and particularly because of the plague. Nevertheless, as people living in a great city, brought up in a correspondingly great way of life, you must be prepared to stand up against the greatest disasters, and not obliterate your reputation... You must put away your private sorrows and work for the safety of the community." [8, \$61]; [9, p.111].

According to Turner and Killian [5, p.259] social movements are semi-rational responses to abnormal conditions. They seek to change individuals, social organizations, institutions, and/or societies. They bring innovative and unconventional elements to civil society. They bring innovative and unconventional elements to civil society. Social movements will form when people sense that something is not quite right in the way their society operates. They often begin after an event which upsets the everyday lives of many individuals and requires a collective response. The social movement then attempts to deal with the structural weaknesses in society that often have a negative psychological affect on individuals and social groups. Social movements gain strength when the regular administrative/ political processes are unable to address the perceived social problem or crises. They may seek to restore things to the way they were before the crisis or call for radical change and a new order

Aberle [11] (see Table 1) identified four types of social movements: alternative; redemptive; reformative; and revolutionary based on whether they seek limited or radical changes and whether they focus on modifying individual behavior or transforming society as a whole. Alterative social movements seek limited social change and tend to be focused on a specific group of people. For example, Planned Parenthood is directed toward people of childbearing age to encourage birth control. Redemptive social movements also focus on a specific group of people but advocate for a radical change in the individual and, by extension, society. This is characteristic of some evangelical religious sects, especially those that recruit members to abandon old lifestyles and be 'reborn.'

Table 1. Abele's four types of social movements

\begin{tabular}{|c|c|c|}
\hline & Limited change & Radical change \\
\hline $\begin{array}{c}\text { Modify Individual or } \\
\text { Group Behavior }\end{array}$ & Alternative & Redemptive \\
\hline $\begin{array}{c}\text { Transform Society as a } \\
\text { Whole }\end{array}$ & Reformative & Revolutionary \\
\hline
\end{tabular}

Reformative social movements advocate for limited social change but seek to affect that change across an entire society. The change may be progressive towards new social relationships or institutions, or it may be retrogressive attempting to restore the status quo ante. For example, the conservationist side of the environmental movement encourages communities to develop programs for recycling paper and plastics. The preservationist side advocates for saving or restoring wilderness and natural areas by ending or limiting access and use by tourists and business interests. Finally revolutionary social movements promote radical change across an entire society that will impact all of society. The Communist party and the Islamic terrorist movements want to radically change political and social institutions.

Although some religious movements are redemptive and aimed at individuals, they may also become reformative when, in Smelser's terms, they attempt to restore, protect, modify or create values in the name of a generalized belief [6, p.313]. Religious movements and secular political movements can become intertwined; witness the role of African American churches and reverends in the U.S. civil rights movement. This can lead to both spiritual and political empowerment. The combination of religious and political movements may also engender civil religion, a collection of sacred and patriotic beliefs, symbols and rituals that strengthens and solidifies a community's political identity and sense of nationhood [10], [12].

\section{The Plague as Collective Behavior}

The Athenian plague and the rise of the cult of Asclepius can be examined as a case study in collective behavior and social movements. The plague first appeared in the second 
year of the Peloponnesian War (431-404 BCE) fought between the Delian League of city-states dominated by Athens and the Peloponnesian League led by Sparta. Several battles were fought in $431 \mathrm{BCE}$ and at the end of the year Pericles delivered his famous Funeral Oration [8, §34-46], [9, p.79-93]. This was part of a burial rite to honor fallen warriors. The oration is an example of Rousseau's [13, §IV,8] civil religion which captures the moral and spiritual underpinnings of Athenian democracy by seeking a common set of values and symbols while allowing citizens in a polytheistic culture to hold other beliefs and practices.

In his speech, Pericles rallies the people, praising the Athenian democratic political system, the openness of the city to the world, and the ability of citizens to adapt to the most varied forms of action with versatility and grace. In his history, Thucydides quickly juxtaposed this view of civil society with the breakdown of normative behavior during the plague.

The next year $(430$ BCE $)$ Sparta invaded Attica and Pericles ordered an evacuation to a secure area behind the Long Walls which Pericles had built (458-456 BCE) linking Athens to the port of Piraeus. The city consequently became overcrowded. The plague raged ferociously during that year and the next causing many deaths and great dejection [3]. Pericles was deposed from his office, tried, and fined, but soon reinstated. Pericles died of a lingering sickness at age 66 in 429 BCE.

The nature of the plague has been the topic of much speculation. However, in 2001 Salmonella typhi bacteria (Typhoid fever) was found in the dental pulp of teeth recovered in remains from a mass grave in the ancient Cemetery of Kerameikos in central Athens [14]. Typhoid fever is spread though ingestion of the bacteria in contaminated food or water. This occurs when excrements and rotten food are not properly disposed of. Symptoms include headaches, high fevers $\left(>39^{\circ} \mathrm{C} ; 102.2 \mathrm{~F}\right)$, diarrhea and chest congestion. Complications include infection, pneumonia, intestinal bleeding or intestinal perforation.

Thucydides [8, §49], [9, p.95-97] reported a plethora of symptoms including ones that are symptoms of typhoid fever: violent heats in the head; pain in the chest accompanied by a hard cough; violent ulceration of bowels; diarrhea and discharges of bile of every kind; and internally the body burned (extremely high fever).

Regardless of the pathology of the epidemic, Thucydides' social description of the plague easily fits into standard categories of collective behavior: rumor, panic, and the breakdown of normative behavior including neglect of burial rites and rise of lawlessness. Atrocity rumors were spread that the plague was spread by traditional enemies. Thucydides [8, §48], [9, p.95] reported that

"The plague is said to have originated in Ethiopia beyond Egypt and then into Egypt and Libya and on much of the King (of Persia's) land. It fell suddenly upon Athens starting in Piraeus and giving rise to the allegation that the Peloponnesians (i.e., the Spartan

\section{Alliance) had put poison into the wells."}

An early social symptom was general desperation. Thucydides $[8, \S 51],[9, \mathrm{p} .101]$ wrote that

"No remedy was found, for what did good in one case, did harm in another. The most terrible feature was the dejection which ensued when anyone felt himself sickening, for the despair into which they instantly fell took away their power of resistance. They witnessed the awful spectacle of men dying like sheep. If they were afraid to visit each other, they perished from neglect... If they ventured to help, death was the consequence. In addition people living outside the city panicked and migrated to the city resulting in overcrowding and more deaths."

Norms were soon ignored. According to Thucydides [8, §52], [9, p.101]

"The disaster was overpowering and as people did not know what would become of them, they tended to neglect the sacred and secular alike. All previously observed funeral customs were disregarded and the dead were buried in any way possible. Some would put their own dead on someone else's pyre while others threw the body they were carrying on the top of an already burning pyre and slip away."

Finally Thucydides $[8, \S 53][9$, p.101-103] reported wide spread lawlessness-anomia.

"When they saw the sudden changes of fortune, people were more willing to dare to do things which they would not previously have admitted to enjoying. No one was willing to persevere in struggling for what was considered an honorable result, since he could not be sure that he would not perish before he achieved it. No fear of the gods or law of men had a restraining power, since it was judged to make no difference whether one was pious or not. No one expected to live long enough to have to pay the penalty for his misdeeds. People felt they had a death sentence hanging over them and therefore they might reasonably get some enjoyment out of what was left of their lives."

Thucydides' observations were essentially echoed by the Presidential Bioethics Commission [15, p.26] when it stated that "Similar to epidemics that have come before, the current Ebola epidemic reveals how social perceptions of infectious diseases can lead to unethical infringement of civil liberties and stigmatization of the ill, those who treat them, and those who otherwise come to be associated with them." However, the Commission did not consider the efficacy or ethics of the use of prayer or other spiritual interventions by local peoples as they attempted to counter the presumed disfavor of powerful forces.

In 2000, the World Health Organization invited two anthropologists to assist in efforts to contain the outbreak of 
Ebola hemorrhagic fever. Hewlett and Hewlett [16, p.112-114] found that African cultural models for epidemic disease have social, economic and spiritual dimensions. But as ordinary treatments failed and the deaths continued, local people shifted from sorcery to containing the epidemic illness including modifying burial and funeral practices.

\section{The Cult of Asclepius as a Social Movement}

The plague subsided but reappeared in the winter of 427 BCE and lasted for about a year. Papagrigorakis [14] estimated that overall one-third of the civilian population and one-fourth of the army perished. Following the devastation of the plague, the Athenians began reestablishing norms and supportive institutions. The rise of the cult of Asclepius can be considered to be a social movement that featured redemptive religious healing and a reformative political strategy. In addition, the rise of the cult paralleled the emergence of the Asclepiad physicians and Hippocratic writings that date between 427 and $400 \mathrm{BCE}$ [17]. This aspect of the movement influenced the development of western scientific medicine.

Once the plague was over, the Athenians regained control of Delos which had been the financial center of the Delian League, until Pericles moved the treasury to Athens in 454 BCE. In 426 BCE the Athenians purified Apollo's temple on the island, had all the tombs removed to a neighboring island and established the Delia festival [18, p.214-215].

Mitchell-Boyask [19] argued that between 430 and 404 BCE Greek theater portrayed the war and the general political health of Athens. Oedipus Rex by Sophocles was first produced at Greater Dionysia in 425 BCE. Sophocles inserted a plague that was not part of the traditional story. The play opens with a priest and chorus asking Oedipus to rid them of the plague. The priest uses the word loimos meaning plague or pestilence in contrast to nosos meaning disease. The chorus prays that "ravenous Ares, whose hot breath I feel as he charges on without bronze shield, but howling battle cries, let him turn back and quickly leave this land."

Thebes, the setting of Oedipus Rex, was not at war; but Athens was in the midst of one. The first round of plague (430 BCE) came with battle, but the second round (427 BCE) did not. Loimos appears only once in the play and then not in other plays of the time period. Mitchell-Boyask [19] suggested that in the post plague years, Sophocles made loimos an unspeakable taboo word. In this way drama would become a part of a healing process of the body politic.

The religious system of ancient Greece consisted of a pantheon of twelve Olympian deities and a set of demigods/ heroes. Many had several epithets indicating a particular role or power. For example Athena was known as Promachos (leader in battle), Polias (guardian of the city), Nike (victory) and Hygieia (healer). Statues and shrines were dedicated to each epithet, several of which were located on the Acropolis
[20, p.15], [21, p.284-85]. Athena was also worshiped in other cities and islands. Although a polis or community might have a special local deity and temple, cults recognized a wide variety of gods and demigods/ heroes, some cults were recognized by the governing assembly or rulers and authorized to hold public festivals in honor of the deity. Many private and family cults existed but were not officially recognized [22].

According to Greek mythology, Asclepius, the god of medicine and healing, was born near Epidaurus which became the site of his earliest sanctuary. In 420/419 BCE, a private citizen, Telemachus, brought the Epidaurian god Asclepius in the guise of his sacred snake from Epidaurus to Athens at his own expense but with the approval of the polis authorities [3], [22]. The sanctuary was located by a spring water on the south slope of the Acropolis near the Theatre of Dionysus where dramas by Sophocles (Oedipus Rex, Ajax) and Aeschylus (Agamemnon) addressed the illnesses of both individuals and the body politic [23, p.83, 129].

Public festivals in honor of Asclepius were placed on the religious calendar. The festival of Epidauria marked the arrival of Asclepius. He was met at Piraeus and taken to Athens by members of the cult of Eleusinian Demeter [23, p.53]. This occurred during the celebration of the Eleusinian Mysteries and meant that each year the cult of Asclepius would be linked with that celebration. Since the cult of Asclepius was an elective cult to which all Greeks, not just Athenian citizens, could choose to join, it was able to become a Pan-Hellenic cult, somewhat above the military and political concerns of the city-states [24, p.85,195].

A second festival, the Asclepieia, was held in conjunction with the cult of Dionysus Eleutheros during which tragedies and comedies were performed within sight of the newly established sanctuary of Asclepius. These festivals attracted people from across Greece and displayed Athenian accomplishments and aspirations [23, p.89].

As a redemptive social movement, the cult of Asclepius renewed religious healing practices that had been disrupted by the war and plague. Athenian women sought the god's assistance in conception and childbirth. Asclepius replaced Artemis Locheia (helper in childbirth); and Athena Hygieia [25, p.106], although the latter was thought of as protecting the health of the city more than individuals. Asclepius also received dedications from parents on behalf of their children or other family members for healing or preventing disease [24, p. 142-143].

The cult would reach Rome during the plague of 293 BCE. After consulting the Sibylline Oracles, the Senate sent Quintus Ogulnius Gallus to Epidaurus to bring Asclepius to Rome to end the plague [26, p.88-94]. As with his introduction into Athens, Asclepius was brought to Rome in the form of a serpent. According to legend, the serpent swam from the boat carrying it to Rome onto Tiber Island. Within a few years the Senate built a temple for Asclepius on Tiber Island. After the plague ended, it became a healing shrine as evidenced by numerous anatomical votives representing the body part to be healed. 


\section{Asclepius and Hippocratic Medicine}

Two aspects, one political and the other medical, mark the cult as a reformative social movement. The importation of the cult of Asclepius into Athens is seen as part of a political strategy by the Athenians to gain the support of Epidaurus and access to a harbor on the Peloponnese [23, p.93-99], [27, p.18]. This was negotiated and occurred during the Peace of Nicias (421 BCE).

The cult of Asclepius also contributed to the development of medicine. The earliest mention of Asclepiads is in the sixth century writings of Theognis of Megara where it seems to refer to a general practitioner. Asclepiadae literally means the family of Asclepius and refers to a hereditary line of physicians who claimed to be descendents of the Homeric physicians. Over time it may have become more guild-like as students were adopted into the family [17, p.39].

By the end of the fifth century BCE, temple and sanctuary based treatments involved fasting and dreaming (incubation) to reveal the cure or prescription [17, p.9], [28, p.13]. Marketos [29] suggested that traditional healing was provided by priests at Asclepieia, therapeutic centers located in temples and sanctuaries. In contrast to this "inpatient" care, the Hippocratic physician provided "outpatient" care by visiting patients in their homes. Hippocrates, among others, favored treatment based on accurate observation of the course of the disease and the patient's living conditions (airs, waters, and places). However, physicians and priests met each other in the healing sanctuaries, perhaps consulting about patients and the efficacy of common treatments like dietary prescriptions [30, p.338].

Hippocrates, a contemporary of Thucydides, was thirty years old when the plague began. Historical evidence does not document his presence in Athens at the time, but that did not prevent others from fictionalizing an attempt to cure the plague with fire [31, p.64]. Both Plato and Aristotle identify him as an Asclepiad, while healers in the sanctuaries of Asclepius were referred to as priests [30]. Nutton [25, p.68, 111-115] argued that the followers of Hippocrates and the priests healers were united against charismatic magicians and wandering shamans who practiced outside religious or secular institutions.

The adherence of the followers of Hippocrates to religious beliefs is clearly evident in the opening of the Hippocratic Oath: "I swear by Apollo, the healer, Asclepius, Hygieia, and Panacea, and I take to witness all the gods, all the goddesses." The oath then lists some professional and religious/ethical obligations including to live a life in purity and holiness, to give no deadly medicine to any one if asked, and not take sexual advantage of patients or reveal confidential information. Physicians began making sacrifices on behalf of themselves and their patients as well as holding processions and games in honor of Asclepius [33].

The concurrent rise of the cult of Asclepius and the Hippocratic corpus were part of the creation of a new school of medicine and marked the beginning of medicine as a scientific discipline and profession which applied a body of knowledge to particular cases and practiced under a code of ethics.

Asclepius possessed the skills, talents and attributes of the good physician and it would be difficult for a physician to reject Asclepius as a symbol and standard for secular healers. It appears that the reformative aspects of the cult of Asclepius as a social movement helped spread Hippocratic medicine and medical ethics throughout the Mediterranean world.

\section{Conclusions}

Sociologists and others who study collective behavior and social movements primarily rely on contemporary or recent historical examples. They have developed a set of theories with which to explain a particular case in terms of a range of factors from individual anxiety to societal strain that may lead to types of social movements that modify individual behavior or transform society. This paper analyzes the plague of Athens and the rise of the cult of Asclepius as an example of collective behavior and a social movement.

Thucydides lived and wrote during the Peloponnesian War and plague of Athens. He was a reflective investigative journalist who today might be writing "Annals of National Security" for The New Yorker magazine. He did not have theories of collective behavior and social movements to guide him, yet his account reveals a sociological imagination and concepts. This is evident in his account of the plague of Athens that included escalating stages of collective behavior: atrocity rumors attributing inhuman acts committed by an enemy; social strains and depression, intense personal terror, mobilized evacuation and panicked fleeing to what appears to be a safer location, overcrowding, acts of altruism in the face of disaster, and disintegration of cultural values and beliefs culminating in not observing burial rituals and general lawlessness (anomia).

As a redemptive social movement the cult of Asclepius offered new religious norms of healing. Although Thucydides reported the arrival of Asclepius in Athens, the subsequent rise of the cult was of little political interest.

The farther away one gets from the rise of the social movement, the more difficult it becomes to separate who did what and when from the later accounts that attribute events to individuals or groups that may or may not have had a part in them.

One could claim that Sophocles served as a champion of the new cult, laying the intellectual and belief groundwork. The personal role of Hippocrates during the plague is a fiction invented by physicians holding the humoral theory of health and disease. But his school separated the theory and practice of medicine and surgery from religious incantations and magical amulets or charms. By being identified as Asclepiads, they were able to replace the charismatic magicians and wandering shamans who had been unable to treat the plague, and were able to complement the care provided by priests in temples and sanctuaries. As Asclepius 
ascended from a local healer to a national and international demigod of medicine, the Hippocratic School thrived and spread across the Mediterranean world over the following centuries.

\section{REFERENCES}

[1] D. L. Miller. Introduction to Collective Behavior and Collective Action 2nd ed. Prospect Heights IL: Waveland Press 2000.

[2] G. D. Hart. Ancient coins and medicine. CMAJ. 1966; 94:77-89.

[3] J. Longrigg. Epidemic, ideas and classical Athenian society. In T. O. Ranger, P. Slack (eds) Epidemics and Ideas: Essays on the Historical Perception of Pestilence, New York: Cambridge University Press; 1992: p. 21-44.

[4] G. Le Bon. The Crowd: A Study of Popular Mind. New York: The Viking Press; 1960.

[5] R. H. Turner, L. M. Killian. Collective Behavior. Englewood Cliffs, NJ: Prentice-Hall; 1957.

[6] N. J. Smelser. Theory of Collective Behavior New York: The Free Press of Glencoe; 1962.

[7] E. Durkheim. Suicide: A Study in Sociology, trans. J. A. Spaulding, J.A. and G. Simpson. New York: The Free Press of Glencoe; 1951.

[8] Thucydides. The Peloponnesian War. Book II. trans. Blanco, W., and Roberts, J.T. New York: W.W. Norton; 1998.

[9] P. J. Rhodes. Thucydides: History II. Warminister, UK: Aris \& Phillips, Ltd.; 1988.

[10] D. A. Nielsen. Pericles and the plague: Civil religion, anomie, and injustice in Thucydides. Sociol Relig. 1996; 57:397-407.

[11] D. F. Aberle. The Peyote Religion among the Navaho. Chicago: Aldine; 1966.

[12] R. Bellah. Civil religion in America. Dædalus. 1967; 96:1-21.

[13] J. J. Rousseau. The Social Contract. New York: Cosimo; 2008:

[14] M. J. Papagrigorakis, C. Yapijakis P. N. Synodinos., E. Baziotopoulou-Valavani. DNA examination of ancient dental pulp incriminates typhoid fever as a probable cause of the Plague of Athens. Int J Infect Dis. 2006; 10:206-14.

[15] Presidential Commission for the Study of Bioethical Issues. ETHICS and EBOLA Public Health Planning and Response. Washington DC. 2015.
[16] B. S. Hewlett, B.L. Hewlett. Ebola, Culture and Politics: The Anthropology of an Emerging Disease. Belmont, CA: Thompson Wadsworth. 2008.

[17] W. H. S. Jones (ed). Hippocrates Collected Works I by Hippocrates. Cambridge MA: Harvard UP; 1968.

[18] J. D. Mikalson. Religion in Hellenistic Athens. Berkeley CA: University of California Press; 1998.

[19] R. Mitchell-Boyask. Plague and theatre in ancient Athens. Lancet. 2009; 373: $374-375$.

[20] J. M. Hurwit. The Athenian Acropolis: History, Mythology and Archaeology from the Neolithic Era to the Present. New York: Cambridge University Press; 1999.

[21] M. L. D'Ooge, The Acropolis of Athens, Charleston, S.C: Nabu Press; 2011.

[22] W. Allan. Religious syncretism: The new gods of Greek tragedy. Harv Stud Classic Philol. 2004; 102:113-155.

[23] B. L. Wickkiser. Asclepius, Medicine, and the Politics of Healing in Fifth-century Greece, Baltimore, MD: Johns Hopkins University Press; 2008.

[24] J. D. Mikalson. Ancient Greek Religion s 2nd ed. Malden MA: Wiley-Blackwell; 2010.

[25] V. Nutton. Ancient Medicine. New York: Routledge; 2004.

[26] G. H. Renberg. Public and private places of worship in the cult of Asclepius at Rome. MAAR. 2006/2007; 51/52: 87-172.

[27] K. Clinton. The Epidauria and the arrival of Asclepius in Athens. In R. Hägg (ed.), Ancient Greek Cult Practice from the Epigraphical Evidence. Stockholm: Swedish Institute at Athens. 1994: p.17-34.

[28] A. A. Sheikh, R. G., Kunzendorf, K. S. Sheikh. Healing images: Historical perspective. In A. A. Sheikh. Healing Images: The Role of Imagination in Health. Amityville, NY: Baywood Publishing Co.; 2003: p. 3-26.

[29] S. Marketos. Origins of nephrology, Greece and Byzantium. Am J Nephrol. 1997; 17:205-208.

[30] H. F. J. Horstmanshoff. Asclepius and temple medicine in Aelius Aristides' sacred tales. In H. F. J. Horstmanshoff, M. Stol, M. (eds) Magic and Rationality in Ancient Near Eastern and Graeco-Roman Medicine. Leiden, the Netherlands: Brill Academic Press; 2004: p 325-341.

[31] J. R. Pinault. How Hippocrates Cured the Plague. J Hist Med Allied Sci. 1986; 41: 52-75.

[32] E.J. Bailey. Asclepius: Ancient hero of medical caring. Ann Intern Med. 1996; 124:257-263.

[33] P. Prioreschi. A History of Medicine: Greek Medicine. vol 2. Omaha: NB: Horatius Press; 1996. 